\title{
Pengembangan Video Pembelajaran IPS Bermuatan Tes untuk Siswa
}

\author{
Ni Komang Rina Ariani ${ }^{1 *}$, Made Sumantri ${ }^{2}$, Desak Putu Parmiti ${ }^{3}$ iD \\ 1,2,3Prodi Pendidikan Guru Sekolah Dasar, Jurusan Pendidikan Dasar, Universitas Pendidikan Ganesha, Singaraja, \\ Indonesia \\ *Corresponding author: rinaariani.id@gmail.com
}

\section{Abstract}

Hasil belajar IPS siswa masih tergolong rendah diakibatkan oleh pembelajaran yang berpusat pada guru, kurangnya pemanfaatan media saat mengajar dan siswa terdorong untuk menghapal informasi. Penelitian ini bertujuan untuk mengetahui validitas isi materi, desain, media dan tes pilihan ganda pada video pembelajaran IPS bermuatan tes untuk siswa kelas V SD. Media pembelajaran yang dikembangkan berupa video pembelajaran. Jenis penelitian dalam penelitian ini adalah development research dengan model 4D yang terdiri dari define, design, develop, dan disseminate. Metode dalam penelitian ini adalah non tes dengan memberikan kuesioner untuk memperoleh penilaian terhadap video pembelajaran yang dilakukan oleh pakar ahli isi materi pembelajaran, ahli media pembelajaran, ahli desain video pembelajaran, dan ahli evaluasi pembelajaran terhadap tes pilihan ganda tanpa melakukan uji coba lapangan dan hanya dilakukan penyebaran video kepada wali kelas. Hasil analisis Pengembangan Video Pembelajaran IPS Bermuatan Tes untuk Siswa Kelas V SD diperoleh hasil: validitas isi materi pembelajaran sebesar 1, validitas desain video pembelajaran sebesar 1, validitas media pembelajaran sebesar 1, dan validitas tes pilihan ganda sebesar 1, dengan perolehan uji validasi sebesar 1 artinya video pembelajaran memperoleh kategori sangat tinggi, serta memperoleh uji reliabilitas isi materi pelajaran 0,99 , uji desain video pembelajaran 0,98 , dan uji media pembelajaran sebesar 0,99 Berdasarkan hasil analisis diperoleh simpulan yakni Video Pembelajaran IPS Bermuatan Tes Untuk Siswa Kelas V SD dinyatakan valid dan reliabel.

Keywords: Development, Video, IPS, Test

\section{Abstract}

Student social studies learning outcomes are still relatively low due to teacher-centered learning, lack of use of the media when teaching and students are encouraged to memorize information. This study aims to determine the validity of the contents of the material, design, media and multiple-choice tests on social studies learning videos containing tests for fifth grade elementary school students. Learning media developed in the form of learning videos. This type of research in this research is development research with $4 D$ models consisting of define, design, develop, and disseminate. The method in this study is non-test by giving a questionnaire to obtain an assessment of learning videos conducted by experts in the content of learning materials, learning media experts, instructional video design experts, and learning evaluation experts on multiple choice tests without conducting field trials and only conducted video distribution to homeroom teacher. The results of the analysis of the Development of Social Studies Learning Videos Loaded Tests for Grade V Elementary School Students obtained the results: the content validity of learning material is 1 , the validity of learning video design is 1 , the validity of instructional media is 1 , and the validity of multiple choice tests is 1 , with the acquisition of validation test of 1 it means that the learning video gets a very high category, and obtains the reliability test of the subject matter content 0.99 , the learning video design test 0.98, and the learning media test is 0.99. Based on the analysis results, it is concluded that the IPS Learning Video Loaded Tests for Class V Students SD is declared valid and reliable

Keywords: Development, Video, IPS, Test

$\begin{array}{lll}\text { History: } & \text { Publisher: Undiksha Press } \\ \text { Received } & \text { : 24 Juni } 2020 & \text { Licensed: This work is licensed under } \\ \text { Revised } & : \text { Juli } 2020 & \text { a Creative Commons Attribution 3.0 License } \\ \text { Accepted } & : \text { 26 Juli } 2020 & \end{array}$




\section{Introduction}

Sumber daya manusia yang bermutu dan berdayaguna diperoleh suatu instansi pendidikan formal yang memiliki peran penting dalam menyiapkan generasi bangsa dalam menghadapi kehidupannya di masa yang akan datang. Salah satu mata pelajaran yang mengembangkan sumber daya manusia yang berkualitas yang mempunyai karakter adalah ilmu pengetahuan social. IPS adalah salah satu matapelajaran yang terdiri dari beberapa muatan materi seperti geografi, sejarah, ekonomi, sejarah, dan sosiologi (Endayani, 2017; Fadhli, 2015; Herijanto, 2012; Hilmi, 2017). Jadi, pelajaran IPS adalah salah satu pembelajaran yang dikembangkan dari berbagai materi yang membatu siswa untuk mengembangkan kemampuan untuk memecahkan masalah yang ada di masyarakat. Nur Hadi (Munandar, 2002) menyebutkan ada 4 tujuan pendidikan IPS, yaitu: pengetahuan (knowledge), keterampilan (skills), sikap dan nilai (attitudes and values). Dari Tujuan tersebut diharapkan pendidikan IPS dapat digunakan untuk mengenal diri mereka sendiri sebagai kemampuan untuk memecahkan masalah pribadi atau masalah sosial serta kemampuan mengambil keputusan dan berpartisipasi dalam berbagai kegiatan kemasyarakatan agar menjadi warga negara yang baik. Kenyataan yang terjadi di lapangan, (Darmayoga, et al, 2013) beranggapan banyak yang menganggap bahwa IPS merupakan pelajaran tidak menarik, peserta didik tidak memperoleh sesuatu yang dapat disimpan dalam memorinya, sulitnya mengingat materi yang cukup banyak, dan sebagian besar siswa mempelajari materi dengan cara menghafal sehingga dampak pendidikan IPS terhadap kehidupan bermasyarakat, masih belum begitu nyata terlihat dan cenderung berdampak negative. Sampai saat ini masih banyak ditemukan kesulitan-kesulitan yang dialami siswa dalam pembelajaran IPS. Kesulitan siswa dalam memahami suatu pelajaran IPS disebabkan karena guru dalam mengajarkan IPS kepada siswa cenderung berpusat kepada guru (teacher centered) (Pane \& Darwis Dasopang, 2017). Guru kurang memperhatikan kemampuan yang dimiliki siswa, umumnya siswa lebih banyak memperoleh pengalaman tak langsung dalam proses pembelajaran. Pembelajaran tersebut akan mendorong anak untuk menghafal informasi, otak anak dipaksa untuk mengingat dan menimbun berbagai informasi tanpa dituntut untuk menghubungkannya dengan kehidupan mereka sehari-hari. Tercapainya tujuan pendidikan khususnya pembelajaran IPS salah satunya dapat dilihat dari hasil belajar IPS yang diperoleh siswa.

Berdasarkan pencatatan dokumen hasil belajar IPS pada siswa Kelas V SD dilihat pada Tabel 1.

Tabel 1. Hasil Belajar IPS Siswa Kelas V SD

\begin{tabular}{ccccccc}
\hline No. & Nama Sekolah & $\begin{array}{c}\text { Jumlah } \\
\text { Siswa }\end{array}$ & $\begin{array}{c}\text { Rata-rata } \\
\text { Nilai UAS } \\
\text { Ilmu }\end{array}$ & KKM & \multicolumn{2}{c}{ Nilai Siswa } \\
\cline { 5 - 6 } & & $\begin{array}{c}\text { Di } \\
\text { Pengetahuan } \\
\text { Sosial }\end{array}$ & & $\begin{array}{c}\text { Dawah } \\
\text { KKM }\end{array}$ & $\begin{array}{c}\text { atas } \\
\text { KKM }\end{array}$ \\
\hline 1 & SDN 1 Pemaron & 36 & 68,03 & 69 & 20 & 16 \\
2 & SDN 2 Pemaron & 23 & 67,56 & 70 & 13 & 10 \\
3 & $\begin{array}{c}\text { SDN 1 } \\
\text { Tukadmungga } \\
\text { SDN 2 } \\
4\end{array}$ & 37 & 66,14 & 66 & 23 & 14 \\
5 & $\begin{array}{c}\text { Tukadmungga } \\
\text { SDN 3 } \\
\text { Tukadmungga }\end{array}$ & 23 & 69,15 & 70 & 14 & 9 \\
\hline
\end{tabular}

(Sumber: Dokumen Guru kelas V di Gugus XIV Kecamatan Buleleng) 
Berdasarkan hasil pengamatan yang dilakukan pada tanggal 23 Oktober 2019 kepada guru kelas yang ada di SDN Gugus XIV Kecamatan Buleleng terdapat beberapa faktor yang mempengaruhi hasil belajar yaitu: (1) guru menyajikan materi lebih sering menggunakan metode ceramah, (2) guru jarang menggunakan media 3) tersedianya fasilitas sekolah berupa LCD yang jarang digunakan guru, sehingga faktor-faktor tersebut berdampak pada hasil belajar IPS kelas V kurang optimal. Berdasarkan Peraturan Pemerintahan Republik Indonesia Nomor 19 tahun 2005, pada pasal 19 ayat 1 disebutkan, "proses pembelajaran diselenggarakan secara interatif, inspiratif, menyengkan, menantang, memotivasi peserta didik untuk berpatisipasi aktif, serta memberikan ruang yang cukup bagi prakarsa, kreativitas dan kemandirian sesuai bakat, minat, dan perkembangan fisik serta psikologi peserta didik". Oleh karena itu pembelajaran IPS di SD tidak dapat diajarkan dengan sebatas hafalan saja (Diarsa, 2017). Melainkan proses pembelajaran ini membutuhkan sebuah alat bantu pembelajaran untuk mempermudah siswa memahami materi yaitu dibuatkan sebuah media. Dengan perangkat pembelajaran yang baik akan menuntun siswa untuk dapat meningkatkan hasil belajar dengan baik, untuk mendapatkan hasil belajar yang baik, sebelumnya siswa harus diimbangi dengan aktivitas belajar yang baik juga (Gading \& Dian Kharisma, 2017). Untuk itu salah satu solusi yang dapat dilakukan adalah dengan penggunaan media video pembelajaran yang dapat menarik dan memudahkan peserta didik untuk memahami materi yang diajarkan.

"Media pembelajaran merupakan saluran atau perantara yang digunakan untuk menyampaikan pesan atau materi ajar" (Azhar, 2008; Yaumi, 2018). Media sangat diperlukan dalam pembelajaran sebagai alat penyampaian informasi dan pesan dari guru kepada peserta didik. Pembelajaran yang baik dan sesuai dengan kondisi kelas. Pada mata pelajaran IPS banyaknya materi pengapalan yang membuat siswa bosan, sehingga media video dirasa dapat menarik perhatian siswa, menjadikan siswa tidak bosan dan tidak sulit dalam menghafal, menurut (Fadhli, 2015). Penggunaan media saat pembelajaran dapat menjadikan peserta didik lebih termotivasi, terlibat aktif secara fisik. Materi IPS yang dijadikan sebagai video dapat ditambahkan dengan gambar-gambar sebagai pendukung dan penjelasan yang dapat memaksimalkan seluruh indera peserta didik dalam belajar, dan menjadikan kegiatan pembelajaran lebih bermakna. Oleh karena itu, video pembelajaran merupakan salah satu media yang sesuai untuk menampilkan materi-materi IPS yang disusun secara sederhana sehingga siswa mudah untuk memahami materi IPS tersebut. Media video pembelajaran adalah alat media atau alat bantu mengajar yang berisi pesan-pesan pembelajaran. Video sebagai media audio visual dan mempunyai unsur gerak akan mampu menarik perhatian dan memotivasi siswa dalam melaksanakan kegiatan pembelajaran. Dengan unsur gerak dan animasi yang dimiliki video, mampu menarik perhatian siswa lebih lama jika dibandingkan dengan media pembelajaran lainnya. Video juga memiliki kelebihan yaitu mampu membantu memahami pesan pembelajaran secara lebih bermakna tanpa terikat oleh bahan ajar lainnya. (Lee, 2011) juga mengatakan pemanfaatan program video dalam kegiatan pembelajaran yaitu 1) memberikan pengalaman yang tak terduga kepada peserta didik, 2) memperlihatkan secara nyata sesuatu yang pada awalnya tidak mungkin bisa dilihat, 3) jika dikombinasikan dengan animasi dan pengaturan kecepatan, dapat mendemonstrasikan perubahan dari waktu ke waktu.

Hal ini didukung dengan beberapa penelitian yang telah membuktikan media video efektif untuk pembelajaran IPS. Melinda et al., (2018) menghasilkan suatu produk media video pembelajaran berbasis Virtual Field Trip (VFT) yang valid sebagai sumber belajar dan efektif untuk pembelajaran IPS di kelas V SD/MI. Kemudian Tegeh et al., (2019) mengemukakan hasil penelitian yang diperoleh yaitu uji lapangan menunjukkan produk berpredikat sangat baik. Efektivitas pengembangan menunjukkan bahwa video pembelajaran Agama Hindu yang dikembangkan efektif meningkatkan hasil belajar Agama Hindu. Darmanta et al., (2016) mendeskripsikan bahwa penelitian yang diperoleh yaitu video pembelajaran efektif meningkatkan hasil belajar Ilmu Pengetahuan Sosial. Adapun sebagai evaluasi media video 
apakah dapat mempengaruhi hasil belajar IPS, diperlukannya tes untuk siswa. Kadir, (2015) tes adalah suatu cara (yang dapat digunakan) atau prosedur (yang perlu untuk ditempuh) dalam rangka pengukuran dan penilaian di bidang pendidikan. Jadi, dapat disimpulkan bahwa penelitian pengembangan video pembelajaran bermuatan tes dipandang dapat meningkatkan hasil belajar IPS siswa kelas V SD. Sehingga tujuan dalam penelitian Pengembangan Video Pembelajaran IPS Bermuatan Tes Untuk Siswa Kelas V SD. Dengan adanya penelitian ini akan diperoleh sebuah media inovatif yang bisa digunakan oleh guru untuk mempermudah proses pembelajaran agar tidak lagi proses pembelajaran yang dilakukan bersifat monoton dan membosankan sehingga berdampak negatif terhadap hasil lulusan.

\section{Materials and Methods}

Model penelitian ini berfokus pada penelitian dan pengembangan yang menghasilkan produk pengembangan berupa Video Pembelajaran bermuatan Tes Dalam Meningkatkan Hasil Belajar IPS di Kelas V SD dengan model pengembangan Thiagarajan, Semmel dan Smmel yang dikenal dengan model 4-D, yang telah termodifikasi dari Ose (2017), terdiri dari 4D yakni: define, design, develop, dan disseminate. Adapun subjek penelitian ini meliputi perangkat pembelajaran berupa video pembelajaran bermuatan tes dalam meningkatkan hasil belajar IPS Siswa Kelas V SD. Variabel dalam penelitian ini hanya terdapat variabel bebas, variabel bebas dalam penelitian ini adalah pengembangan video pembelajaran IPS bermuatan tes. Video pembelajaran adalah produksi dan penggunaan materi yang penerapannya melalui pandangan dan pendengaran serta tidak seluruhnya tergantung kepada pemahaman kata atau simbol-simbol yang serupa. Tes merupakan salah satu pengembangan kompetensi secara berkelanjutan di bidang penilaian yang memanfaatkan Teknologi Informasi dan Komunikasi dalam penyusunannya. Dengan menggunakan tes dapat mengukur suatu aspek perilaku siswa dan terdapat umpan balik terhadap hasil tes yang dikerjakan oleh siswa karena siswa akan mengetahui kesalahan yang dilakukan dalam menyelesaikan tes yang diberikan

Langkah-langkah penelitian pengembangan perangkat pembelajaran berupa Video Pembelajaran IPS Berbantuan Tes Untuk Siswa Kelas V SD mengikuti langkah-langkah model pengembangan 4D yang telah termodifikasi dari Ose (2017), terdiri dari define, design, develop, dan disseminate dengan keterbatasan hanya dilakukan penyebaran video pembelajaran pada wali kelas tanpa diadakan uji coba, adapun langkah-langkah yang digunakan adalah: (1) Tahap pendefinisian (Define): (a) Analisis awal akhir yang digunakan untuk mengetahui kesulitan siswa serta beberapa fakta yang dapat dijadikan bahan pertimbangan dalam penyusunan perangkat yakni: melakukan observasi kepada guru kelas $\mathrm{V}$ di SD tentang pendekatan pembelajaran yang diterapkan pada mata pelajaran IPS, dengan permasalahan yang di hadapi adalah guru kelas $\mathrm{V}$ belum menggunakan media yang relevan dan inovatif terkait dengan pembelajaran IPS. Selain itu permasalahan yang ditemui selanjutnya (a) guru kurang menggunakan media pembelajaran dan proses pelaksanaan pembelajaran di kelas masih berpusat pada guru dan hasil. (b) Analisis hasil belajar siswa kelas $\mathrm{V}$ pada mata pelajaran IPS masih di bawah KKM. (c) Terdapat fasilitas di sekolah, namun jarang digunakan guru. (2) Tahap merancang (Design): (a) Pemilihan format menggunakan media audio visual berupa video pembelajaran (b) pemilihan media, yakni media yang digunakan dalam penelitian ini adalah benda-benda yang ada di sekolah. (3) Tahap pengembangan (Develop): (a) Validasi produk, hasil dari perencanaan desain dan pembuatan produk awal tersebut selanjutnya dinilai (validasi) ke ahli media pembelajaran, (b) revisi produk, berdasarkan validasi ahli, data yang masuk selanjutnya digunakan sebagai acuan dalam revisi desain, (d) hasil produk akhir, setelah semua langkah dilakukan dan tidak ada revisi maka produk akhir yang dihasilkan adalah video pembelajaran IPS bermuatan tes. (4) Tahap penyebaran (Disseminate): karena berbagai keterbatasan maka tahap penyebaran dalam 
penelitian ini yakni video pembelajaran, maka hanya disebarkan kepada wali kelas tanpa melakukan uji coba lapangan.

Metode pengumpulan data dikumpulkan melalui pelaksanaan evaluasi formatif yaitu data hasil review ahli isi/ materi bidang studi dan data hasil review ahli media pembelajaran dan data hasil review ahli desain pembelajaran. Data-data yang telah terkumpul, kemudian dikelompokkan menurut sifatnya menjadi dua yaitu: data kualitatif dan kuantitatif. Data kualitatif dan kuantitatif diperoleh dari hasil review ahli isi bidang studi atau mata pelajaran melalui angket tanggapan, hasil review ahli media pembelajaran, ahli desain video pembelajaran bermuatan tes. Metode pengumpulan data tersebut menggunakan empat metode yaitu (1) kuesioner/ angket, (2) wawancara, (3) pencatatan dokumen, dan (4) tes tertulis. Instrumen yang digunakan untuk mengumpulkan data dalam penelitian pengembangan ini yaitu sebagai berikut. Kuesioner/ Angket, menurut Agung (2014) "metode kuesioner/ angket merupakan cara memperoleh atau mengumpulkan data dengan mengirim suatu daftar pertanyaan/ pernyataan-pernyataan kepada responden/ subjek penelitian". Dalam penelitian ini angket tanggapan digunakan untuk mengumpulkan data hasil review dari ahli isi bidang studi atau mata pelajaran, ahli media pembelajaran dan ahli desain pembelajaran. Wawancara, menurut (Agung, (2014) "metode wawancara adalah suatu metode pengumpulan data dengan cara melakukan tanya jawab yang sistematis, dan hasil tanya jawab ini dicatat/ direkam secara cermat". Wawancara digunakan untuk mengumpulkan data mengenai masalah pembelajaran yang terjadi di lapangan. Pencatatan dokumen digunakan untuk mengumpulkan data rancang bangun pengembangan produk berdasarkan wawancara dengan guru mata pelajaran IPS berupa nilai hasil UTS semester ganjil tahun 2019/2020 siswa kelas V SD.

Item-item instrumen yang telah disusun berdasarkan kisi-kisi terlebih dahulu dilakukan uji validitas. Validitas isi digunakan untuk mengetahui ketepatan instrumen dalam suatu variabel yang diukur. Menurut Sugiyono (2015) bahwa yang dimaksud dengan, "Validitas isi adalah validitas yang data dibantu dengan menggunakan kisi-kisi instrumen". Instrumen ini berbentuk dari skala lima, Widoyoko (dalam Vindaswari \& Ulfah, 2018) yang terdiri dari skor (1) sangat kurang baik, (2) kurang, (3) cukup, (4) baik, dan (5) sangat baik. Pada penelitian ini, validasi instrumen diperoleh dari penilaian yang dilakukan oleh pakar/ ahli (expert judgement). Pada kisi-kisi terdapat variabel yang diteliti, indikator sebagai tolak ukur dan nomor butir (item) pertanyaan atau pernyataan yang telah dijabarkan dari indikator. Untuk menguji validitas butir-butir instrumen lebih lanjut, maka setelah dikonsultasikan dengan ahli, selanjutnya diuji cobakan.

Validitas instrumen menggunakan formula Gregory (dalam Candiasa, 2017). Adapun tahapan-tahapan menentukan validitas isi, sebagai berikut: Pakar/ ahli memberikan penilaian terhadap instrumen per butir dengan menggunakan skala 1 tidak relevan, skala 2 cukup relevan, skala 3 relevan, dan skala 4 sangat relevan, dilakukan dengan pengelompokan skala, misalnya skala 1 dan 2 dikelompokkan menjadi kurang relevan dan skala 3 dan 4 dikelompokkan menjadi sangat relevan, selanjutnya menabulasi hasil penelitian pakar kedalam bentuk matriks tabulasi silang (2x2) dan memasukan data hasil tabulasi silang ke dalam rumus validitas isi. Matriks tabulasi silang, dan nilai validitas isi kemudian dikategorikan pada tabel kategori validitas isi.

Reliabilitas sama dengan konsistensi atau keajegan sebuah instrumen, butir-butir instrumen yang telah valid diuji reliabilitasnya. Teknik uji reabilitas dalam penelitian ini menggunakan rumus Alpha Cronbach. Rumus Alpha Cronbach digunakan karena kuesioner yang digunakan berbentuk angket dengan skor skala bertingkat. Arikunto (2015) menyatakan bahwa "rumus Alpha digunakan untuk mencari reliabilitas instrumen". 


\section{Results and Discussion}

Pengembangan video pembelajaran IPS bermuatan tes pada siswa kelas V SD mengikuti langkah-langkah model pengembangan 4D terdiri dari define, design, develop, dan disseminate dengan keterbatasan hanya dilakukan penyebaran rencana pelaksanaan pembelajaran pada wali kelas tanpa diadakan uji coba. Adapun hasil dari tahap develop (pengembangan) perangkat pembelajaran ini setelah melaksanakan perbaikan dan revisi adalah a) validasi produk, hasil dari perencanaan desain dan pembuatan produk awal tersebut selanjutnya dinilai (validasi) ke ahli kurikulum mengenai isi mata pelajaran dimana terlebih dahulu dibuatkan kisi-kisi untuk instrumen pengujian validitas ahli isi mata pelajaran terdiri dari aspek: 1) materi, 2) kalimat, 3) evaluasi, 4) belajar mandiri. Tahap selanjutnya uji validitas desain pembelajaran, adapun kisi-kisi pengujian validitas desain video pembelajaran terdiri dari aspek: 1) konsistensi, 2) desain cover, 3) desain pesan teks, 4) desain pesan gambar, 5) desain pesan video, 6) pengorganisasian video, dan 7) sampul belakang. Uji validitas isi media pembelajaran terdiri dari aspek: 1) tujuan/ kompetensi, 2) karakteristik siswa, 3) metode, dan 4) evaluasi, dan uji validitas tes berbentuk pilihan ganda dengan kisi-kisi indikator sebagai berikut: 1) mengurutkan peristiwa kedatangan bangsa barat yang menjajah Indonesia, 2) menentukan faktor-faktor pendorong penjajahan bangsa barat di Indonesia, 3) menemukan kebijakan yang dilakukan oleh penjajahan bangsa Barat di Indonesia, dan 4) menampilkan upaya-upaya perlawanan bangsa Indonesia terhap penjajahan Bangsa barat. Setelah dilaksanakan uji validitas maka tahap selanjutnya adalah uji reliabilitas untuk mengetahui keajegan dari sebuah perangkat pembelajaran.

Adapun hasil uji validitas video pembelajaran dan reliabilitas video pembelajaran ditampilkan pada Tabel 2.

Tabel 2. Hasil Uji Validitas dan Reliabilitas Video Pembelajaran Bermuatan Tes

\begin{tabular}{ccccccc}
\hline No & $\begin{array}{c}\text { Uji Video } \\
\text { Pembelajaran }\end{array}$ & $\begin{array}{c}\text { Jumlah Item } \\
\text { Kuesioner }\end{array}$ & Skor & $\begin{array}{c}\text { Nilai Uji } \\
\text { Validitas }\end{array}$ & $\begin{array}{c}\text { Nilai Uji } \\
\text { Reliabilitas }\end{array}$ & Kategori \\
\hline 1 & Isi Mata Pelajaran & 20 & 97 & 1 & 0.99 & $\begin{array}{c}\text { Sangat } \\
\text { Tinggi }\end{array}$ \\
\hline 2 & $\begin{array}{c}\text { Desain Video } \\
\text { Pembelajaran }\end{array}$ & 29 & 112 & 1 & 0.98 & $\begin{array}{c}\text { Sanggat } \\
\text { Tinggi }\end{array}$ \\
\hline 3 & $\begin{array}{c}\text { Isi Media } \\
\text { Pembelajaran }\end{array}$ & 20 & 86 & 1 & 0.99 & $\begin{array}{c}\text { Sangat } \\
\text { Tinggi }\end{array}$ \\
\hline 4 & Tes Pilihan Ganda & 15 & 15 & 1 & 1 & Relevan \\
\hline
\end{tabular}

Berdasarkan Tabel 2 Hasil Uji Validitas dan Reliabilitas Video Pembelajaran Bermuatan Tes diperoleh Uji isi materi pelajaran memperoleh skor 97. Selanjutnya, video pembelajaran IPS bermuatan tes untuk siswa kelas V SD berdasarkan koreksi dari pakar ahli isi materi pembelajaran setelah perbaikan dan konsultasi kembali diperoleh validitas berdasarkan perhitungan dapat disimpulkan bahwa 20 item kuesioner memperoleh nilai 1 yang artinya validitas isi materi pelajaran berdasarkan tabel kategori validitas isi yakni sangat tinggi. Uji desain video pembelajaran memperoleh skor 112. Selanjutnya, video pembelajaran IPS bermuatan tes untuk siswa kelas V SD berdasarkan koreksi dari pakar media pembelajaran setelah perbaikan dan konsultasi kembali diperoleh validitas berdasarkan perhitungan dapat disimpulkan bahwa 29 item kuesioner memperoleh nilai 1 yang artinya validitas isi kuesioner berdasarkan tabel kategori validitas isi yakni sangat tinggi. Uji isi media pembelajaran yakni diperoleh skor 86. Selanjutnya, berdasarkan koreksi dari pakar desain video pembelajaran setelah perbaikan dan konsultasi kembali, validitas berdasarkan perhitungan dapat disimpulkan bahwa 20 item kuesioner memperoleh nilai 1 yang artinya validitas isi kuesioner berdasarkan tabel kategori validitas isi yakni sangat tinggi. uji validitas tes pilihan ganda dengan hasil uji 
validitas pakar memperoleh nilai 1 yang termasuk kategori sangat tinggi serta bermasuk kepada interpretasi sangat kuat.

Setelah video pembelajaran IPS bermuatan tes untuk siswa kelas V SD yang dinyatakan valid maka selanjutnya diuji reliabilitasnya dengan rumus alpha cronbach r11. Hasil uji reliabilitas isi mata pelajaran diperoleh hasil sebesar 0.99 dan validitas isi mata pelajaran memiliki interpretasi sangat tinggi serta dapat dinyatakan reliabel, hasil perhitungan 29 butir item kuesioner mengenai desain video pembelajaran yang telah dinyatakan valid diperoleh hasil sebesar 0.98 dan 29 butir memiliki interpretasi sangat tinggi serta dapat dinyatakan reliabel. perhitungan 20 butir item kuesioner mengenai isi media pembelajaran IPS bermuatan tes untuk siswa kelas V SD diperoleh hasil sebesar 0.99 dan memiliki interpretasi sangat tinggi serta dinyatakan reliabel.

Adapun masukan, saran, dan komentar yang diberikan oleh dosen sebagai sebagai berikut ini: pada bagian video soal terlalu cepat dan perbaiki rentangan waktu penyajian soal. Sedangkan, masukan, saran, dan komentar dari ahli media pembelajaran sebagai berikut; (1) tujuan pembelajaran di RPP tidak menyertakan siswa menonton video, (2) sertakan tujuan dan indikator I dalam video, (3) gunakan bahasa yang ringan dan membuat siswa ingin tahu, (4) supaya siswa termotivasi video di dubbing memakai suara sendiri, (5) tentukan mana pesan yang mau ditonjolkan apakah teks atau gambar, (6) beberapa contoh cari yang berwarna, (7) supaya lebih menarik, video di dubbing memakai suara sendiri, (8) sertakan tujuan pembelajaran dalam setiap video, (9) tidak ada penjelasan di awal video, (10) soal terlalu cepat, walaupun bisa di pause akan mengurangi makna pengemasan dalam bentuk video. Tema/ sub tema video diperjelas. Selanjutnya, masukan, saran, dan komentar dari ahli desain media pembelajaran yakni: (1) tema/ sub tema video diperjelas, (2) cantumkan kelas dan semester, (3) cantumkan tujuan pembelajaran di video, (4) tambahkan sampul pada bagian depan video, (5) tambahkan narasi berupa suara, karena tidak semua siswa bisa belajar dengan gaya visual tetapi ada juga yang belajar dengan gaya auditory (b) hasil produk akhir, setelah semua langkah dilakukan dan tidak ada revisi maka produk akhir yang dihasilkan adalah video pembelajaran IPS bermuatan tes untuk siswa kelas V SD.

Pengembangan video pembelajaran bermuatan tes merupakan salah satu pengembangan kompetensi secara berkelanjutan di bidang penilaian yang memanfaatkan teknologi informasi dan komunikasi dalam penyusunannya, penggunaan video sebagai media audio visual dalam pembelajaran IPS pada materi penjajahan bangsa barat di Indonesia tentunya sangat menguntungkan bagi guru karena guru bisa membuat video sendiri sesuai dengan karakteristik siswa dan lingkungan siswa. Ahmad Susanto (2015) menyatakan bahwa "Guru memiliki peranan penting dalam pelaksanaan pendidikan, yang sangat berpengaruh dalam proses pembelajaran. Di samping itu, sebagai media pembelajaran dalam mata pelajaran IPS, video juga mempermudah guru dalam menyampaikan materi tentang peristiwa masa lalu penjajahan bangsa barat di Indonesia. Zendrato (2016) menyatakan bahwa rancangan yang disiapkan sebelum mengajar akan membantu guru untuk mengajar lebih terarah. Oleh karena itu, siswa akan bisa mencapai hasil belajar yang baik. Berdasarkan hal tersebut banyak faktorfaktor yang mendukung agar terciptanya hasil belajar siswa yang baik (Firmansyah, 2015). Penampikan materi pembelajaran pada video dan bermuatan tes dapat memudahkan siswa untuk belajar dengan menggunakan gaya belajar baik visual maupun audiotori. Tes yang ditampilkan pada video juga dapat mencegah kebocoran soal dan membuat siswa fokus untuk melihat soal yang ditampilkan pada video. Manfaat yang tak kalah pentingnya adalah dengan tes formatif dalam bentuk tes disertai umpan balik akan mengakibatkan motivasi peserta didik untuk lebih giat belajar dan semakin antusias dalam mengikuti pelajaran pada saat guru memberikan umpan balik.

Pengembangan video pembelajaran IPS bermuatan tes untuk siswa kelas V SD diperoleh hasil perhitungan uji validitas mengenai isi materi pada video pembelajaran telah 
dinyatakan valid diperoleh hasil uji sebesar 0.99 dan memiliki interpretasi sangat tinggi serta dapat dinyatakan reliabel. Berdasarkan hasil perhitungan validasi video mengenai desain media pembelajaran yang telah dinyatakan valid diperoleh hasil sebesar 0.99 memiliki interpretasi sangat tinggi serta dapat dinyatakan reliabel, dan berdasarkan hasil perhitungan validasi ahli media pembelajaran yakni video dinyatakan valid diperoleh hasil sebesar 0.99 hasil validasi memiliki interpretasi sangat tinggi serta dapat dinyatakan reliabel, dan hasil validasi tes pilihan ganda pada video pembelajaran IPS memperoleh hasil validitas 1 dan berada pada kategori sangat tinggi. Hasil uji validitas dan reliabilitas isi materi pembelajaran, media pembelajaran, dan desain pembelajaran ini sesuai dengan penelitian sebelumnya yakni penelitian yang dilakukan oleh Darmanta et al. (2016) dengan isi materi pembelajaran IPS pada kualifikasi sangat baik sehingga isi konten/ konten media video pembelajaran tidak perlu direvisi, uji ahli media pembelajaran berada pada kualifikasi sangat baik, dan hasil uji desain pembelajaran pada kualifikasi sangat baik Selanjutnya penelitian yang dilaksanakan oleh Yuanta (2017) dari hasil persentase siswa media pembelajaran IPS berupa video sangat valid digunakan dalam proses pembelajaran, menurut (Pratiwi, 2018) media yang dapat diterapkan dalam pembelajaran IPS salah satunya adalah media video, keunggulan media video yang mampu menampilkan gambaran bergerak dan suara merupakan satu daya tarik sendiri, karena siswa mampu menyerap pesan atau informasi yang disampaikan dengan menggunakan lebih dari satu Indra, dan menurut Fadhli (2015) pengembangan media pembelajaran berbasis video meningkatkan prestasi belajar IPS siswa.

Hal ini didukung dengan beberapa penelitian yang telah membuktikan media video efektif untuk pembelajaran IPS. Melinda et al. (2018) menghasilkan suatu produk media video pembelajaran berbasis Virtual Field Trip (VFT) yang valid sebagai sumber belajar dan efektif untuk pembelajaran IPS di kelas V SD/MI. Kemudian Tegeh et al. (2019) hasil penelitian yang diperoleh yaitu uji lapangan menunjukkan produk berpredikat sangat baik. Efektivitas pengembangan menunjukkan bahwa video pembelajaran Agama Hindu yang dikembangkan efektif meningkatkan hasil belajar Agama Hindu. Darmanta et al. (2016) mendeskripsikan bahwa penelitian yang diperoleh yaitu video pembelajaran efektif meningkatkan hasil belajar Ilmu Pengetahuan Sosial.

\section{Conclusion}

Adapun simpulan dalam penelitian ini adalah sebagai berikut: Video pembelajaran IPS bermuatan tes untuk siswa kelas V SD yang dikembangkan tanpa melalui uji coba lapangan dan hanya dapat dinyatakan valid dengan hasil dari segi isi materi video pada interpretasi validitas sangat tinggi serta layak untuk digunakan, dari segi media pembelajaran video pada interpretasi validitas sangat tinggi serta layak untuk digunakan, dari segi desain video pembelajaran video pada interpretasi validitas sangat tinggi serta layak untuk digunakan, dan dari segi tes pilihan ganda hasil validasi tes pilihan ganda pada video pembelajaran IPS memperoleh hasil validitas berada pada kategori sangat tinggi. Video pembelajaran IPS bermuatan tes untuk siswa kelas V SD dapat dinyatakan reliabel dengan diperoleh reliabilitas video pembelajaran dari segi isi materi pada interpretasi sangat tinggi serta layak untuk digunakan, dari segi media pembelajaran pada interpretasi sangat tinggi serta layak untuk digunakan, dari segi desain video pembelajaran pada interpretasi sangat tinggi serta layak untuk digunakan dan dari segi tes pilihan ganda memperoleh hasil pada kategori sangat tinggi serta dapat dinyatakan reliabel.

\section{References}

Agung, A. A. G. (2014). Metodelogi Penelitian Pendidikan. Universitas Pendidikan Ganesha. Ahmad Susanto, Teori Belajar Dan Pembelajaran Di Sekolah Dasar,(Jakarta: Kencana Prenada 
Media Group, 2013). (2015). Motif Sosial. In Biomass Chem Eng.

Arikunto, S. (2015). Dasar-Dasar Evaluasi Pendidikan. Bumi Aksara.

Azhar, A. (2008). Media pembelajaran; Edisi revisi. In Repositori Riset Kesehatan Nasional. https://doi.org/http://perpustakaan.bppsdmk.kemkes.go.id//index.php?p=show_detail\&id $=4667$

Candiasa, I. M. (2017). Pengembangan Tes Bakat Terpadu Online. JST (Jurnal Sains Dan Teknologi). https://doi.org/10.23887/jst-undiksha.v5i2.8270

Darmanta, G., Suwatra, I. W., \& Parmiti, D. P. (2016). Pengembangan Video Pembelajaran Pada Mata Pelajaran Ips Kelas Vi Semester Genap Di Sd Negeri 2 Banyuning Tahun Pelajaran 2015-2016. Jurusan Teknologi Pendidikan, 5.

Darmayoga, I. W., Lasmawan, I. W., \& Marhaeni, A. A. I. N. (2013). Pengaruh Implementasi Metode Mind Mapping Terhadap Hasil Belajar Ips Ditinjau Dari Minat Siswa Kelas Iv Sd Sathya Sai Denpasar. PENDASI: Jurnal Pendidikan Dasar Indonesia.

Diarsa, I. P. (2017). "Pengaruh Model Pembelajaran Two Stay Two Stray Berbantuan Media Visual Terhadap Hasil Belajar IPA Siswa." E-Jurnal PGSD Universitas Pendidikan Ganesha Mimbar PGSD, 5.

Endayani, H. (2017). Pengembangan materi ajar ilmu pengetahuan sosial. Jurnal Program Studi Pendidikan Ilmu Pengetahuan Sosial, 1(1), 92-110. http://jurnal.uinsu.ac.id/index.php/ijtimaiyah/article/download/1158/922

Fadhli, M. (2015). Pengembangan Media Pembelajaran Berbasis Video Kelas Iv Sekolah Dasar. Jurnal Dimensi Pendidikan Dan Pembelajaran, 3, 24-29.

Firmansyah, D. (2015). Pengaruh Strategi Pembelajaran Dan Minat Belajar Terhadap Hasil Belajar Matematika. Jurnal Pendidikan Unsika, 3, 34-44.

Gading, I. K., \& Dian Kharisma, K. (2017). Pengaruh Model Pembelajaran Kooperatif Tipe Make A Match Berbantuan Media Audio Visual Terhadap Hasil Belajar Ips Sekolah Dasar. International Journal of Elementary Education. https://doi.org/10.23887/ijee.v1i2.11608

Herijanto, B. (2012). Pengembangan Cd Interaktif Pembelajaran Ips Materi Bencana Alam. JESS (Journal of Educational Social Studies), 1(1), 8-12. https://doi.org/10.15294/jess.v1i1.73

Hilmi, M. Z. (2017). Implementasi Pendidikan IPS Dalam Pembelajaran IPS Di Sekolah. Jurnal Ilmiah Mandala Education, 3(2), 164-172. https://doi.org/http://dx.doi.org/10.36312/jime.v3i2.198

Kadir, A. (2015). Menyusun Dan Menganalisis Tes Hasil Belajar. Al-Ta'dib.

Lee, W.-M. (2011). Using Eclipse for Android Development. Beginning Android Application Development. https://doi.org/10.1053/seiz.2002.0679

Melinda, V. A., Degeng, N. S., \& Kuswandi, D. (2018). Pengembangan Media Video Pembelajaran IPS Berbasis Virtual Field Trip (VFT) Pada Kelas V SDNU Kratonkencong. JINOTEP (Jurnal Inovasi Dan Teknologi Pembelajaran): Kajian Dan Riset Dalam Teknologi Pembelajaran. https://doi.org/10.17977/UM031V3I22017P158

Munandar, U. (2002). Kreativitas dan Keterbakatan. In Kreativitas dan Keberbakatan.

Peraturan Pemerintahan Republik Indonesia Nomor 19 tahun 2005 tentang standar nasional pendidikan. Journal of Chemical Information and Modeling. https://doi.org/10.1007/978- 


\section{1-4614-7990-1}

Ose, L. (2017). No Title. KREANO: Jurnal Matematika Kreatif-Inovatif, 1, 101-108.

Pane, A., \& Darwis Dasopang, M. (2017). Belajar Dan Pembelajaran. Fitrah:Jurnal Kajian Ilmu-Ilmu Keislaman. https://doi.org/10.24952/fitrah.v3i2.945

Pratiwi Lanjar. (2018). Media Video: Solusi Pembelajaran Ips Bagi Siswa Sekolah Dasar. Seminar Nasional Pendidikan Era Revolusi, 337-350.

Sugiyono. (2015). Metode Penelitian. Metode Penelitian.

Tegeh, I. M., Simamora, A. H., \& Dwipayana, K. (2019). Pengembangan Media Video Pembelajaran Dengan Model Pengembangan 4D Pada Mata Pelajaran Agama Hindu. Julnar Mimbar Ilmu.

Vindaswari, R. F., \& Ulfah, A. (2018). Pengembangan Buku Cerita Anak Bergambar Berbasis Nilai-Nilai Kepedulian Bagi Peserta Didik Kelas 2 Sekolah Dasar. Fundamental Pendidikan Dasar, 1(Picture Children's Story Book, Concern Values), 148-160.

Yaumi, M. (2018). Media dan Teknologi Pembelajaran. In Jakarta.

Yuanta, F. (2017). Pengembangan Media Audio Visual Mata Pelajaran Bahasa Indonesia Untuk Sekolah Dasar. Ibriez: Jurnal Kependidikan Dasar Islam Berbasis Sains. https://doi.org/10.21154/ibriez.v2i2.36

Zendrato, J. (2016). Tingkat Penerapan Rencana Pelaksanaan Pembelajaran Dalam Pelaksanaan Pembelajaran Di Kelas Suatu Studi Kasus di SMA Dian Harapan Jakarta. Scholaria: Jurnal Pendidikan Dan Kebudayaan, 6(2), 58. https://doi.org/10.24246/j.scholaria.2016.v6.i2.p58-73. 